Provided by the author(s) and University of Galway in accordance with publisher policies. Please cite the published version when available.

\begin{tabular}{|c|l|}
\hline Title & $\begin{array}{l}\text { The Relationship between Inflation and Inflation Uncertainty in } \\
\text { the UK: 1885-1998 }\end{array}$ \\
\hline Author(s) & Fountas, Stilianos \\
\hline $\begin{array}{c}\text { Publication } \\
\text { Date }\end{array}$ & 2000 \\
\hline $\begin{array}{c}\text { Publication } \\
\text { Information }\end{array}$ & $\begin{array}{l}\text { Fountas, S. (2000) "The Relationship between Inflation and } \\
\text { No. 0048) Department of Economics, National University of } \\
\text { Ireland, Galway. }\end{array}$ \\
\hline Publisher & National University of Ireland, Galway \\
\hline Item record & http://hdl.handle.net/10379/1200 \\
\hline
\end{tabular}

Downloaded 2023-04-26T03:36:02Z

Some rights reserved. For more information, please see the item record link above. 


\title{
The Relationship between Inflation and Inflation Uncertainty in the UK: 1885-1998
}

\author{
Stilianos Fountas ${ }^{*}$
}

Working Paper No. 48

September 2000

Department of Economics

National University of Ireland, Galway

http://www.nuigalway.ie/ecn/

E-mail: steve.fountas@nuigalway.ie

\footnotetext{
* The paper was completed while the author was visiting the University of York and the University of California, San Diego.
} 


\begin{abstract}
Using a long series of UK inflation data, I have provided strong evidence in favour of the hypothesis that inflationary periods are associated with high inflation uncertainty. This result supports the Friedman-Ball hypothesis and has important implications for the inflation-output relationship provided that more inflation uncertainty leads to lower output.
\end{abstract}

JEL Classification: C22, E31

Keywords: Inflation, Inflation Uncertainty, Conditional Variance. 


\section{Introduction}

The relationship between the inflation rate and inflation uncertainty has attracted considerable interest by theoretical and empirical macroeconomists since the publication of Milton Friedman's (1977) Nobel lecture. Friedman (1977) analysed the causal effect of inflation on inflation uncertainty and output growth while subsequent theoretical research looked also at the opposite direction of causality, running from inflation uncertainty to the rate of inflation. Despite the considerable volume of primarily empirical research on the relationship between inflation and inflation uncertainty, the empirical literature to date has supplied contradictory evidence regarding the impact of the inflation rate on inflation uncertainty. To this end, this study purports to pursue an empirical analysis by looking at a long period of data for the UK that has been characterised by significant variations in the rate of inflation and inflation uncertainty.

Economists have appealed to the uncertainty about the future rate of inflation in order to account for the welfare loss that monetary economics has associated with inflation. Predictable inflation should not lead to welfare loss since indexation will allow agents to minimize the costs of inflation. However, uncertainty about future inflation distorts the efficient allocation of resources that is based on the price mechanism. This distortion, according to Friedman (1977) will lead to lower output. Furthermore, high inflation rates might result in more variable inflation and, hence, create more uncertainty about future inflation. Combining the link of inflation to inflation uncertainty and the link of inflation uncertainty to output, we have the testable hypothesis that higher inflation leads to lower output, i.e. a positively-sloped Phillips curve.

Friedman's intuitive result has also been subsequently derived formally by Ball (1992) in an asymmetric information game where the public faces uncertainty about the type of the policymaker. The two types of policymaker differ in terms of their willingness to bear the economic costs of reducing inflation. In periods of low inflation, the tough type will apply contractionary monetary policy. Ball assumes that the two types of policymakers alternate in office in a stochastic manner. Therefore, a 
higher current inflation rate creates more uncertainty about the level of future inflation since it is not known whether the tough type will gain power and fight inflation.

Okun (1971) is one of the first studies to find that countries experiencing a high inflation rate are also countries where the standard deviation of inflation is large. The empirical approach to the inflation-uncertainty relationship faces the issue of measuring uncertainty. Two measures of uncertainty that have been used widely in empirical studies are the dispersion of survey-based individual forecasts and the moving standard deviation of inflation. The major disadvantage of these measures lies in their inability to distinguish between variability and uncertainty. In other words, they include both predictable and unpredictable variability, even though the former does not imply any uncertainty. In contrast, the use of the autoregressive conditional heteroskedasticity $(\mathrm{ARCH})$ and generalised $\mathrm{ARCH}(\mathrm{GARCH})$ approaches introduced by Engle (1982) and Bollerslev (1986), respectively, allow us to proxy uncertainty using the conditional variance of unpredictable shocks to the inflation rate. Engle (1983) and Bollerslev (1986), making use of the ARCH techniques, did not perform a statistical test of the Friedman-Ball hypothesis but only compared the estimated conditional variance series with the US average inflation rate over various time periods. They found no significant relation between the two series. Overall, the empirical evidence on the Friedman-Ball view is rather mixed. Ball and Cecchetti (1990), Cukierman and Wachtel (1979), Evans (1991), and Grier and Perry (1998), among others, provide evidence in support of a positive influence of the average rate of inflation on inflation uncertainty. On the other hand, Baillie et al. (1996), Cosimano and Jansen (1988) and Fischer (1981), among others, find no significant relationship between inflation and inflation uncertainty. A recent summary of this evidence is presented in Davis and Kanago (2000).

This study contributes to the literature on the inflation-uncertainty relationship by using a long series on UK inflation rates that span over 100 years, a period characterised by significant variability in the inflation rate. For this period, I find strong evidence in favour of the Friedman-Ball hypothesis. The rest of the letter is outlined as follows: Section 2 provides the model, and section 3 discusses the data and the results. Finally, section 4 summarizes the major conclusions. 



\section{The model}

Consider an $\mathrm{AR}(\mathrm{p})$ model of inflation $\mathrm{y}_{\mathrm{t}}$ with time-varying conditional variance:

$\mathrm{y}_{\mathrm{t}}=\phi_{0}+\phi_{1} \mathrm{y}_{\mathrm{t}-1+\ldots . .} \phi_{\mathrm{p}} \mathrm{y}_{\mathrm{t}-\mathrm{p}}+\varepsilon_{\mathrm{t}}$

$\mathrm{E}\left(\varepsilon_{\mathrm{t}} / \theta_{\mathrm{t}-1}\right)=0$

$\operatorname{Var}\left(\varepsilon_{\mathrm{t}} / \theta_{\mathrm{t}-1}\right)=\sigma_{\mathrm{t}}^{2}$

$\sigma_{\mathrm{t}}^{2}=\alpha+\alpha_{1} \varepsilon_{\mathrm{t}-1}^{2}+\ldots+\alpha_{\mathrm{q}} \varepsilon_{\mathrm{t}-\mathrm{q}}^{2}+\beta_{1} \sigma_{\mathrm{t}-1}^{2}+\ldots \beta_{\mathrm{v}} \sigma_{\mathrm{t}-\mathrm{v}}^{2}+\delta \mathrm{y}_{\mathrm{t}}$

where $\alpha>0, \quad \alpha \geq 0, i=1, \ldots, q, \beta_{j} \geq 0, j=1, \ldots, v$ and $\theta_{t}$ is the information set available at time t. According to the Friedman-Ball hypothesis, $\delta>0$.

\section{Data and results}

I use annual data on UK consumer price index (CPI) for the period 1885-1998. The data for the 1885-1987 period are taken from Liesner (1989) and the data for the rest of the period are from the International Financial Statistics supplied by the IMF. The plot of the inflation series, constructed as the percentage change in the CPI is given in Figure 1. It is obvious that inflation has been quite volatile throughout the sample period.

Table 1 shows some descriptive statistics for the inflation series and the Box-Pierce Q statistics of autocorrelation of the deviations and the squared deviations of inflation from its sample mean. The results imply a deviation from normality and evidence in favour of ARCH effects. I, then, employ ADF and Phillips-Perron unit root tests (results not reported) and conclude that inflation is I(1). I, therefore, estimate various GARCH models where the inflation series follows an ARMA model. The best of these models, chosen in terms of the minimum value of the Akaike Information Criterion (AIC) and the Schwarz Bayesian Criterion (SBC) is a $\operatorname{GARCH}(1,1)$ model where the inflation series follows an AR(1) process. This model is presented in Table 2. The reported diagnostics indicate the lack of serial correlation in the estimated residuals and the squared residuals. The dummy variable in the inflation equation captures high-inflation periods in the sample. It takes the value one during the periods 1915-18, 1974-77 and 1979-80. The positive and strongly significant sign of 
the estimated parameter $\delta$ in the conditional variance equation provides strong support to the Friedman-Ball hypothesis.

\section{Conclusions.}

Using a long series of UK inflation data, I have provided strong evidence in favour of the hypothesis that inflationary periods are associated with high inflation uncertainty. This result supports the Friedman-Ball hypothesis. It also has important implications for the inflation-output relationship provided that more inflation uncertainty leads to lower output. 


\section{References}

Baillie, R., C-F. Chung and Tieslau, M. 1996. Analyzing inflation by the fractionally integrated ARFIMA-GARCH model. Journal of Applied Econometrics, 11: 23-40.

Ball, L. 1992. Why does high inflation raise inflation uncertainty? Journal of Monetary Economic, 29: 371-388.

Ball, L. and S. Cecchetti. 1990. Inflation and uncertainty at short and long horizons. Brookings Papers on Economic Activity, 1: 215-245.

Bollerslev, T. 1986. Generalized autoregressive conditional heteroskedasticity. Journal of Econometrics, 31: 307-327.

Cosimano, T. and D. Jansen. 1988. Estimates of the variance of US inflation based upon the ARCH model. Journal of Money, Credit and Banking, 20: 409-421.

Cukierman, A. and A. Meltzer. 1986. A theory of ambiguity, credibility, and inflation under discretion and asymmetric information. Econometrica, 54: 1099-1128.

Cukierman, A. and P. Wachtel. 1979. Differential inflationary expectations and the variability of the rate of inflation. American Economic Review, 595-609.

Davis, G. and B. Kanago. 2000. The level and uncertainty of inflation: Results from OECD forecasts. Economic Inquiry, 38: 58-72.

Engle, R. 1982. Autoregressive conditional heteroskedasticity with estimates of the variance of UK inflation. Econometrica, 50: 987-1008.

Engle, R. 1983. Estimates of the variance of US inflation based upon the ARCH model. Journal of Money, Credit and Banking, 15: 286-301. 
Evans, M. 1991. Discovering the link between the inflation rate and inflation uncertainty. Journal of Money, Credit and Banking, 23: 169-184.

Fischer, S. 1981. Towards an understanding of the costs of inflation: II. CarnegieRochester Conference series on public policy: 5-41.

Friedman, M. 1977. Inflation and unemployment. Journal of Political Economy, 85: 451-472.

Grier, K. and M. Perry. 1998. On inflation and inflation uncertainty in the G7 countries. Journal of International Money and Finance, 17: 671-689.

Liesner, T., 1989. One hundred years of Economic Statistics. New York: Facts on File, Inc.

Okun, A., 1971. The mirage of steady inflation. Brookings Papers on Economic Activity, 2: 485-498. 
Table 1: UK Inflation: 1885-1998

\begin{tabular}{|c|c|}
\hline Descrictive Statistics & Correlations of $\mathbf{y}-\bar{y}$ \\
\hline Mean $=0.0366$ & $\mathrm{Q}(1)=50.761(0.00)$ \\
\hline Maximun $=0.2278$ & $\mathrm{Q}(2)=73.931(0.00)$ \\
\hline Minimum $=-0.2053$ & $\mathrm{Q}(4)=94.105(0.00)$ \\
\hline Standard deviation $=0.0608$ & Correlations of $(\mathbf{y}-\bar{y})^{\mathbf{2}}$ \\
\hline Skewness $=0.29546$ & $\mathrm{Q}^{2}(1)=16.703(0.00)$ \\
\hline Kurtosis $=5.8757$ & $\mathrm{Q}^{2}(2)=23.249(0.00)$ \\
\hline Jarque-Bera statistic $=40.5798(0.00)$ & $\mathrm{Q}^{2}(4)=26.157(0.00)$ \\
\hline
\end{tabular}

Note: $p$-values are given in parentheses.

Table 2: A GARCH(1,1) model for inflation

Inflation equation: AR(1)

\begin{tabular}{|c|c|c|c|}
\hline Variable & coefficient & Standard error & p-value \\
\hline intercept & 0.012 & 0.004 & 0.006 \\
\hline $\mathrm{y}(-1)$ & 0.491 & 0.084 & 0.000 \\
\hline Dummy & 0.096 & 0.012 & 0.000 \\
\hline
\end{tabular}

Variance equation

\begin{tabular}{|c|c|c|c|}
\hline Variable & coefficient & Standard error & p-value \\
\hline intercept & 0.000 & 0.000 & 0.057 \\
\hline ARCH(1) & 0.266 & 0.110 & 0.015 \\
\hline GARCH(1) & 0.550 & 0.093 & 0.000 \\
\hline$y$ & 0.003 & 0.001 & 0.007 \\
\hline
\end{tabular}

$\bar{R}^{2}=0.550$

Standard error of regression $=0.041$

$\mathrm{AIC}=-3.851$

$\mathrm{SBC}=-3.682$

$\mathrm{Q}(1)=0.04(0.837)$

$\mathrm{Q}^{2}(1)=0.33(0.564)$

$\mathrm{Q}(2)=0.11(0.947)$

$\mathrm{Q}^{2}(2)=2.23(0.327)$

$\mathrm{Q}(4)=4.58(0.333)$

$\mathrm{Q}^{2}(4)=2.52(0.641)$

Note: $\mathrm{Q}(\mathrm{k})$ stands for the Box-Pierce statistic of order $\mathrm{k}$ of the estimated residuals. $\mathrm{Q}^{2}(\mathrm{k})$ is the BoxPierce statistic of the squared residuals. The numbers in parentheses following the statistics are $\mathrm{p}$ values. AIC is the Akaike Information Criterion and SBC the Schwarz Bayesian Criterion. 


\section{Working Paper Series}

No. 48 September 2000 "The Relationship between Inflation and Inflation Uncertainty in the UK: 1885-1998." Stilianos Fountas.

No. 47 August 2000 "A GARCH Model of Inflation and Inflation Uncertainty with Simultaneous Feedback." Stilianos Fountas, Menelaos Karanasos, Marika Karanassou.

No. 46 July 2000 "Do Ordering Effects Matter in Willingness-to-pay Studies of Health Care?" Jennifer Stewart, Eamon O'Shea, Cam Donaldson, Phil Shackley.

No. 45 March 2000 "On the Axiomatic Approach to Freedom as Opportunity: A General Characterization Result.” Ruvin Gekker.

No. 44 March 2000 "On the Axiomatic Ranking of Opportunity Sets in a Logical Framework." Ruvin Gekker.

No. 43 March 2000 "Does the Exchange Rate Regime Affect Export Volumes? Evidence from Bilaterial Exports in the US-UK Trade: 1900-1998," Stilianos Fountas and Kyriacos Aristotelous.

No. 42 November 1999 "Cambridge Distribution in a World Economy," Joan O'Connell. (Forthcoming in The Journal of Income Distribution).

No. 41 November 1999 "Commuting Distances and Labour Market Areas: Some Preliminary Insights from a Spatial Model of Job Search,” Michael J. Keane.

No. 40 September 1999 "The Impact of the Exchange Rate Regime on Exports: Evidence from Bilateral Exports in the European Monetary System," Kyriacos Aristotelous and Stilianos Fountas. (Published in the Journal of Economic Integration, Vol. 15, No. 3, 2000).

No. 39 June 1999 "Measuring Trends in Male Mortality by Socio-Economic Group in Ireland: A Note on the Quality of Data," Eamon O'Shea.

No. 38 June 1999 "The Impact of the Exchange Rate Regime on Exports: Evidence from the European Monetary System," Stilianos Fountas and Kyriacos Aristotelous.

No. 37 June 1999 "Emerging Stock Markets Return Seasonalities: the January Effect and the Tax-Loss Selling Hypothesis," Stilianos Fountas and Konstantinos N. Segredakis. (Forthcoming in Applied Financial Economics).

No. 36 June 1999 "Agricultural entrepreneurs as entrepreneurial partners in land-use management: a policy-based characterization," Scott R. Steele 
No. 35 June 1999 "The Monetary Transmission Mechanism: Evidence and Implications for European Monetary Union," Stilianos Fountas and Agapitos Papagapitos. (Forthcoming in Economics Letters).

No. 34 May 1999 "Exchange rate pass-through, the terms of trade and the trade balance," Eithne Murphy and Lelio Iapadre.

No. 33 May 1999 "The Impact of Health Status on the Duration of Unemployment Spells and the Implications for Studies of the Impact of Unemployment on Health Status," Jennifer Stewart.

No. 32 December 1998 "Subsidies in Irish Fisheries: Saving Rural Ireland?," Vilhjàlmur Wiium.

No. 31 October 1998 "Has the European Monetary System Led to More Exports? Evidence from Four European Union Countries," Stilianos Fountas and Kyriacos Aristotelous. (Published in Economics Letters, Vol. 62, No. 3, 1999).

No. 30 October 1998 "Real Interest Rate Parity under Regime Shifts: Evidence for Industrial Countries," Jyh-lin Wu and Stilianos Fountas. (Forthcoming in The Manchester School).

No. 29 October 1998 "Analyzing Gender-Based Differential Advantage: A Gendered Model of Emerging and Constructed Opportunities,” Scott R. Steele.

No. 28 September 1998 "The Impacts of Transition on the Household in the Provinces of Kazakhstan: The Case of Aktyubinsk Oblast," Pauric Brophy.

No. 27 July 1998 "A Comparison of the Effects of Decommissioning, Catch Quotas, and Mesh Regulation in Restoring a Depleted Fishery," J. Paul Hillis and Vilhjàlmur Wiium.

No. 26 July 1998 "The Sensitivity of UK Agricultural Employment to Macroeconomic Variables," Patrick Gaffney.

No. 25 July 1998 "The Economic and Social Costs of Alzheimer's Disease and Related Dementias in Ireland: An Aggregate Analysis," Eamon O'Shea and Siobhán O'Reilly. Published in International Journal of Geriatric Psychiatry, Vol. 14, 1999.

No. 24 July 1998 "Testing for Real Interest Rate Convergence in European Countries," Stilianos Fountas and Jyh-lin Wu. (Published in the Scottish Journal of Political Economy, Vol. 46, No. 2, 1999).

No. 23 April 1998 "Production, Information and Property Regimes: Efficiency Implications in the Case of Economies of Scope," Scott R. Steele.

No. 22 April 1998 "An Empirical Analysis of Short-Run and Long-Run Irish Export Functions: Does Exchange Rate Volatility Matter?," Donal Bredin, Stilianos Fountas, Eithne Murphy. 
No. 21 April 1998 "Technology and Intermediation: the Case of Banking," Michael J. Keane and Stilianos Fountas.

No. 20 March 1998 "Are the US Current Account Deficits Really Sustainable?," Stilianos Fountas and Jyh-lin Wu. (Published in the International Economic Journal, Vol. 13, No. 3, 1999).

No. 19 December 1997 "Testing for Monetary Policy Convergence in European Countries," Donal Bredin and Stilianos Fountas. (Published in the Journal of Economic Studies, Vol. 25, No. 5, 1998).

No. 18 September 1997 "New Fields of Employment: Problems and Possibilities in Local and Community Economic Development," Michael J. Keane.

No. 17 September 1997 "Estimation of the Impact of CAP Reform on the Structure of Farming in Disadvantaged Areas of Ireland," Eithne Murphy and Breda Lally.

No. 16 May 1997 "Exchange Rate Volatility and Exports: the Case of Ireland," Stilianos Fountas and Donal Bredin. (Published in Applied Economics Letters, Vol. 5, No. 5, 1998)

No. 15 May 1997 "Tests for Interest Rate Convergence and Structural Breaks in the EMS," Stilianos Fountas and Jyh-lin Wu. (Published in Applied Financial Economics, Vol. 8, No. 1, 1998)

No. 14 May 1997 "Cointegration Tests of the Profit-Maximising Equilibrium in Greek Manufacturing 1958--1991," Theodore Lianos and Stilianos Fountas. (Published in International Review of Applied Economics, Vol. 11, No. 3, 1997)

No. 13 April 1997 "Agriculture and the Environment in Ireland: Directions for the Future," Eithne Murphy and Breda Lally. (Published in Administration, Vol. 46, No. 1, 1998)

No. 12 March 1997 "Male Mortality Differentials by Socio-Economic Group in Ireland," Eamon O'Shea. (Published in Social Science and Medicine, Vol.45, No.6, 1997)

No. 11 July 1996 "Testing for the Sustainability of the Current Account Deficit in Two Industrial Countries," Jyl-Lin Wu, Stilianos Fountas and Show-Lin Chen. (Published in Economics Letters, Vol. 52, No. 2, 1996)

No. 10 April 1996 "Towards Regional Development Programmes in Russia," Michael Cuddy.

No. 9 April 1996 "Uncertainty in the General Theory and A Treatise on Probability," Joan O'Connell. 
No. 8 December 1995 "Some Evidence on the Export-Led Growth Hypothesis for Ireland," Stilianos Fountas. (Published in Applied Economics Letters, Vol. 7, No. 4, pp. 211-214, 2000).

No. 7 November 1995 "Caring and Theories of Welfare Economics," Eamon O'Shea and Brendan Kennelly.

No. 6 September 1995 "The Relationship Between Inflation and Wage Growth in the Irish Economy," Stilianos Fountas, Breda Lally and Jyh-Lin Wu. (Published in Applied Economics Letters, Vol. 6, No. 6, 1999).

No. 5 September 1995 "Quality and Pricing in Tourist Destinations," Michael J. Keane. (Published in Annals of Tourism Research, Vol. 24, No. 1, 1997)

No. 4 September 1995 "An Empirical Analysis of Inward Foreign Direct Investment Flows in the European Union with Emphasis on the Market Enlargement Hypothesis," Kyriacos Aristotelous, Stilianos Fountas. (Published in the Journal of Common Market Studies, Vol. 30, No. 4, 1996)

No. 3 September 1995 "The Social Integration of Old People in Ireland," Joe Larragy and Eamon O'Shea.

No. 2 September 1995 "Caring and Disability in Long-Stay Institutions," Eamon O'Shea and Peter Murray. (Published in the Economic and Social Review, Vol. 28, No. 1, 1997)

No. 1 September 1995 “Are Greek Budget Deficits 'too large'?” Stilianos Fountas and Jyh-lin Wu. (Published in Applied Economics Letters, Vol. 3, No. 7, 1996).

\section{Enquiries:}

Department of Economics,

National University of Ireland, Galway.

Tel: $\quad+353-91-524411$, ext. 2177

Fax: +353-91-524130

Email: claire.noone@nuigalway.ie

Web: http://www.nuigalway.ie/ecn/ 